\title{
Approaches of psychoanalysis in the care of the elderly: an integrative review
}

\author{
Álvaro da Silva Santos' \\ Araceli Albino² \\ Vitória de Ávila Santos 3 \\ Gabriela Souza Granero ${ }^{3}$ \\ Maria Teresa Mendonça de Barros² \\ Marta Regina Farinelli ${ }^{3}$
}

\section{Abstract}

Objective: to map publications about the clinical psychoanalytical care of the elderly and describe their characteristics. Method: an integrative review was carried out, considering the period 2008 to 2017 using the following databases: Index-Psychology, LILACS, MedLine, PubMED, SciELO and RedALyC, irrespective of language. The terms Elderly (Idoso), Aging (Envelhecimento) and Psychoanalysis (Psicanálise) were used. The guiding question was: what scientific literature exists about the elderly and psychoanalytical clinical care? A total of 33 articles were considered. Results: five categories were constructed: "Elderly clinical care with a psychoanalytical approach" (15), "Psychoanalytical Approaches in old age" (9), "Psychoanalytical Interventions in long-term care facilities" (6), "Representations of old age for health professionals in the light of psychoanalysis" (2) and "Generationality and psyche" (1). The concern of psychoanalysis for the elderly is incipient and precedes epistemological issues, meaning that production regarding clinical practice is greater; in turn, there are fewer research studies, as most of the articles are reflective in nature. Conclusion: the published studies indicate the possibility of employing psychoanalysis with the elderly, as the unconscious does not age and symptoms are continuously updated. The timidity of psychoanalysis in contrast to the increase in the numbers of elderly persons may be criticized. It is also emphasized that the losses, the effects on the body and the reduction of social ties require adjustments in clinical care, such as the inclusion of group activities and activities beyond the analytical setting, especially hospitals, homes and LTCFs.

\footnotetext{
Universidade Federal do Triângulo Mineiro, Instituto de Ciências da Saúde, Programa de Pós-graduação em Atenção à Saúde. Uberaba, Minas Gerais, Brasil.

2 Núcleo Brasileiro de Pesquisas Psicanalíticas, Programa de Pós-graduação em Psicanálise. Vila Mariana, São Paulo, Brasil.

3 Universidade Federal do Triângulo Mineiro, Instituto de Educação, Letras, Artes Ciências Humanas e Sociais, Programa de Pós-graduação em Psicologia. Uberaba, Minas Gerais, Brasil.
}

Keywords: Aged.

Psychoanalysis. Health of the Elderly. Old Age. 


\section{INTRODUCTION}

The United Nations Fund for Population Activities estimates that there were 15 million elderly people in the world in 2010, and that this number will climb as high as 20 million by the year $2051^{1}$. This development could hardly be overlooked by the field of psychoanalysis. While the effectiveness of this approach among people over 50 was initially questioned, such an idea is no longer valid. ${ }^{2}$.

Psychoanalysis has introduced a new form of understanding human beings. The human psyche is formed by the preconscious/conscious and unconscious systems, which is understood by subjectivity. To speak of the psychic apparatus leads rapidly to a reference to the drives that make up the same, in its articulation to the registering of the symbolic and, therefore, to language ${ }^{3}$.

The elderly are prone to suffering losses of all natures: bodily changes, retirement, the loss of social status, the death of loved ones, and the ghosts of death itself ${ }^{4}$ which can be elaborated by psychoanalytic practice.

Finitude emphasizes feelings of helplessness and distress. Remembrance may emerge as a way of dealing with this distress, through the re-signification and reconstruction of identity ${ }^{5}$.

One of the main issues of the psychoanalytical treatment of the elderly is the fact that the timelessness of the unconscious intersperses with chronological time, where the presence of bodily alterations ${ }^{6}$ (whether through senility or senescence) is frequent. To this we must add a certain distancing from the psychoanalytic field that precedes the Freudian orientations of the past when dealing with psychoanalysis for those aged over $50^{2}$.

In considering contemporaneity and the rapid aging process, there are aspects that cannot be overlooked when using psychoanalysis in the care of the elderly. The present study therefore aims to map publications that deal with the psychoanalytic care of the elderly and their specific characteristics.

\section{METHOD}

An integrative review was carried out. This allows the synthesis of knowledge and the incorporation of significant studies in the practice, and is considered an instrument of Evidence Based Practice ${ }^{7}$. The guiding question was: What scientific literature exists about the elderly and psychoanalytical care?

The search was carried out in February 2018 and considered the period from 2008 to 2017, using the following databases: Psychological-Index, LILACS, MedLine, PubMED, SciELO and RedALyC, in any language. The following descriptors were used: elderly (idoso), aging (envelhecimento), psychoanalysis (Psicanálise), composed as follows: (elderly OR idoso) AND (aging OR envelhecimento) AND (psychoanalysis OR psicanálise).

Repeat articles, editorials, books, course papers, studies where full access was not possible, those that did not respond to the guiding question or which were published outside the period considered were excluded. The selection of the articles occurred in three stages:

1) search for articles according to listed descriptors, period and databases. This phase identified 198 articles;

$2^{\circ}$ ) application of exclusion factors. A total of 51 articles remained;

$\left.3^{\circ}\right)$ interpretative reading of the 51 articles, where 18 were excluded, as they did not address the guiding question, leaving 33 articles.

The articles were read in full and categorized based on thematic similarities.

\section{RESULTS}

A total of 33 articles were considered, of which 14 were published in LILACS, seven in the Psychology Index (VHL Psi), seven in PubMED, three in SciELO and two in RedALyC. The numbers of articles per year were as follows: 2008-3, 2009-1, 2010-1, 2011-8, 2012-4, 2013-1, 2014-6, 2015-6, 
2016-2 and 2017-1. The following types of article were identified: 19 Reflections, six Case Studies, five Surveys and three Experience Reports.

From the survey, five categories were created: "Elderly Clinical Care with a Psychoanalytical Approach" (15), "Psychoanalytical Approaches in Old Age" (9), "Psychoanalytical Interventions in Long-term Care Facilities For The Elderly" (6), "Representations of Old Age for Health Professionals in the Light of Psychoanalysis" (2) and "Generationality and the Psyche" (1).

\section{Elderly Clinical Care with a Psychoanalytical Approach}

The articles in this category are described in Chart 1 and discuss the clinical pathways in the treatment of the elderly.

\section{Psychoanalytical approaches in old age}

The articles in this category are described in Chart 2 , and address the psychoanalytic views about the elderly individual.

\section{Psychoanalytical Interventions in Long-term Care Facilities For The Elderly}

The articles in this category are described in Chart 3, and address the psychoanalytic work in Long-Term Care Facilities For the Elderly (LTCF).

\section{Representations of Old Age for Health Professionals in the Light of Psychoanalysis}

The articles in this category are described in Chart 4 and deal with how health professionals see old age.

Chart 1. Clinical treatment of elderly persons with a psychoanalytical approach. Uberaba, Minas Gerais, 2018.

\begin{tabular}{|c|c|c|}
\hline Title & Proposal of Study & Synopsis \\
\hline $\begin{array}{l}\text { Care of the elderly as an } \\
\text { intersubjective field: ethical } \\
\text { reflections }{ }^{8} \text {. }\end{array}$ & $\begin{array}{l}\text { Reflection on the } \\
\text { care of the elderly } \\
\text { with a basis in } \\
\text { intersubjectivity. }\end{array}$ & $\begin{array}{l}\text { Four types of intersubjectivities were described: transobjective } \\
\text { (difference between the Self and the Other), traumatic (the } \\
\text { other in a constitutive and traumatic relationship), interpersonal } \\
\text { (symmetrical/horizontal relationship between the Self and } \\
\text { the Other) and intrapsychic (based on psychoanalytic theory } \\
\text { - the relationship between the Self and its introjected psychic } \\
\text { objects). The ethics of caring is described in the sense that the } \\
\text { elderly should assume self-care as much as possible. }\end{array}$ \\
\hline $\begin{array}{l}\text { Clinical Considerations } \\
\text { The psychoanalysis of } \\
\text { aging } \\
\text { in the SUS: the CRI- } \\
\text { Norte?. }\end{array}$ & $\begin{array}{l}\text { Experience Report } \\
\text { on the management } \\
\text { of a Winnicottian } \\
\text { psychoanalytic clinic } \\
\text { in the SUS. }\end{array}$ & $\begin{array}{l}\text { The use of brief psychodiagnosis and individual and group } \\
\text { psychotherapy and thematic therapeutic groups. The dependence } \\
\text { of humans themselves is described. The valorization of feeling } \\
\text { oneself in the cycle of real life, and being alive (in Winnicotti), } \\
\text { which is beyond the determinism of diseases. }\end{array}$ \\
\hline $\begin{array}{l}\text { Aesthetics and poetics of } \\
\text { old age in autobiographical } \\
\text { narratives: a study in the } \\
\text { light of psychoanalysis }{ }^{5} \text {. }\end{array}$ & $\begin{array}{l}\text { Reflection on } \\
\text { autobiographical } \\
\text { writing as a } \\
\text { technique. }\end{array}$ & $\begin{array}{l}\text { Autobiography is defended as a technique for proposing } \\
\text { sublimation, desexualization, and the use of written } \\
\text { words to give vent to the drives of the elderly. The use of } \\
\text { group workshops in which the elderly recall facts for the } \\
\text { resignification of identity and the remaking of their social place } \\
\text { and relations is described. }\end{array}$ \\
\hline $\begin{array}{l}\text { Directing clinical } \\
\text { treatment of the elderly }{ }^{10} \text {. }\end{array}$ & $\begin{array}{l}\text { A reflection on } \\
\text { psychoanalytical } \\
\text { care for the elderly, } \\
\text { focusing on the } \\
\text { symptom. }\end{array}$ & $\begin{array}{l}\text { Analysis is performed with the unconscious which does not age } \\
\text { and not with the aged body and, as such, the symptom brings } \\
\text { up to date the inscribed marks. There are no symptoms of the } \\
\text { old but rather old symptoms, which are primary marks. Many } \\
\text { elderly people have many bodily symptoms that are a form of } \\
\text { pleasure, of weaving a bond with the "other". }\end{array}$ \\
\hline
\end{tabular}


Continuation of Chart 1

\begin{tabular}{|c|c|c|}
\hline Title & Proposal of Study & Synopsis \\
\hline $\begin{array}{l}\text { Psychoanalysis and aging: } \\
\text { clinical considerations }{ }^{11} \text {. }\end{array}$ & $\begin{array}{l}\text { Case study with } \\
\text { elderly woman in } \\
\text { panic syndrome and } \\
\text { "delicate surgery". }\end{array}$ & $\begin{array}{l}\text { After surgery, the elderly woman requested medical care, since } \\
\text { she now has an "artificial organ". This "signifier" referred to } \\
\text { existential questions. The analytical work allowed resignification } \\
\text { and the search for activities to give meaning to her life. }\end{array}$ \\
\hline $\begin{array}{l}\text { Older Adults and } \\
\text { psychoanalytic treatment: } \\
\text { it's about time }{ }^{12} \text {. }\end{array}$ & $\begin{array}{l}\text { Case study with } \\
\text { elderly woman } \\
\text { hospitalized in a } \\
\text { Geriatric Psychiatry } \\
\text { Clinic. }\end{array}$ & $\begin{array}{l}\text { Analysis sessions three times a week for } 18 \text { months in the } \\
\text { hospital and then for three further years after discharge. } \\
\text { Transfer was observed with the patient feeling herself } \\
\text { motivated to change, tolerant towards her frustrations and } \\
\text { searching for new meanings in life. }\end{array}$ \\
\hline $\begin{array}{l}\text { Winnicotti and the } \\
\text { challenge of care for } \\
\text { elderly patients in a } \\
\text { confused state }{ }^{13} \text {. }\end{array}$ & $\begin{array}{l}\text { Qualitative research } \\
\text { with categorization } \\
\text { performed with four } \\
\text { elderly women in a } \\
\text { confused state, in an } \\
\text { orthopedic hospital. }\end{array}$ & $\begin{array}{l}\text { Two categories were elucidated: "characterization of the clinical } \\
\text { picture" and "performances of the Psychotherapist". In the } \\
\text { former the patients suffered attention and consciousness } \\
\text { disturbances, memory loss and confusion. In the second } \\
\text { category, the condition of the patients prevented traditional } \\
\text { analysis using holding, from the perspective of reception } \\
\text { and support. Like with the care of the psychotic, listening, } \\
\text { reception, guidance for the family and team had an effect. }\end{array}$ \\
\hline $\begin{array}{l}\text { Special problems for the } \\
\text { elderly psychoanalyst in the } \\
\text { psychoanalytic process }{ }^{14} \text {. }\end{array}$ & $\begin{array}{l}\text { Reflection on the } \\
\text { special conditions } \\
\text { of elderly } \\
\text { psychoanalysts in the } \\
\text { therapeutic process. }\end{array}$ & $\begin{array}{l}\text { The condition of the elderly psychoanalyst as a context requires } \\
\text { awareness of his or her existence and continuous monitoring } \\
\text { of transference and countertransference, avoiding silent, } \\
\text { dangerous and unconscious interaction with his or her patients. }\end{array}$ \\
\hline $\begin{array}{l}\text { Psychoanalysis and old age: } \\
\text { are the elderly obsolete }{ }^{15} \text {. }\end{array}$ & $\begin{array}{l}\text { Psychoanalytical } \\
\text { reflection on } \\
\text { the elderly in a } \\
\text { University hospital } \\
\text { outpatient clinic. }\end{array}$ & $\begin{array}{l}\text { The patient gives authenticity to his or her illness as much as he } \\
\text { or she can, and the doctor contributes to this antidepressants } \\
\text { that instead of "elaborating his or her context" makes the } \\
\text { patient numb. In the analytic perspective, pain, recurrent falls, } \\
\text { forgetfulness should be seen in the elderly in the subjective } \\
\text { dimension. }\end{array}$ \\
\hline $\begin{array}{l}\text { Pour une approche } \\
\text { intégrative de la maladie } \\
\text { d'Alzheimer: pertinence et } \\
\text { limites }^{16} \text {. }\end{array}$ & $\begin{array}{l}\text { Reflection of the } \\
\text { need to combat } \\
\text { Alzheimer's beyond } \\
\text { neurological issues. }\end{array}$ & $\begin{array}{l}\text { The concept of a memory trait from psychoanalytic and } \\
\text { neuropsychological theories is described. Forgetfulness in } \\
\text { Alzheimer's disease may be a defense mechanism that is rooted } \\
\text { in a "desire for forgetfulness" associated with traumatic loss, } \\
\text { leading to real psychic suicide. }\end{array}$ \\
\hline $\begin{array}{l}\text { Aging in the light of } \\
\text { psychoanalysis }{ }^{4} \text {. }\end{array}$ & $\begin{array}{l}\text { Reflection on losses } \\
\text { experienced by the } \\
\text { elderly. }\end{array}$ & $\begin{array}{l}\text { Argues that the age of neurosis is more important than } \\
\text { chronological age, necessitating the elaboration of loss, } \\
\text { mourning, and reinventing life. }\end{array}$ \\
\hline $\begin{array}{l}\text { The aging of Anna } \\
\text { Freud's diagnostic profile: } \\
\text { a re-examination and } \\
\text { re-application of the } \\
\text { psychoanalytic assessment } \\
\text { for older adults }{ }^{17} \text {. }\end{array}$ & $\begin{array}{l}\text { Case study of the } \\
\text { applicability of } \\
\text { the Anna Freud } \\
\text { diagnostic profile in } \\
\text { the elderly }\end{array}$ & $\begin{array}{l}\text { Case study of a } 70 \text {-year-old woman using Ana Freud's } \\
\text { diagnostic profile technique for greater clarity, intrapsychic } \\
\text { diagnosis or understanding. }\end{array}$ \\
\hline $\begin{array}{l}\text { The workshop of } \\
\text { letters, photographs and } \\
\text { souvenirs as a group } \\
\text { psychotherapeutic } \\
\text { intervention with the } \\
\text { elderly }^{18} \text {. }\end{array}$ & $\begin{array}{l}\text { Winnicottian } \\
\text { psychoanalytic } \\
\text { research, developed } \\
\text { in a group of six } \\
\text { elderly people. }\end{array}$ & $\begin{array}{l}\text { The mediating materiality was used. Patients were invited to } \\
\text { bring letters, photographs, or other souvenirs. There were } 16 \\
\text { weekly meetings of } 90 \text { minutes each. The objects were placed } \\
\text { on a magnetic board and the group talked about what they } \\
\text { brought up. They were then photographed and recorded for a } \\
\text { new memory. The socialization of the meanings of the objects } \\
\text { allowed affective exchanges and projection of the future. }\end{array}$ \\
\hline
\end{tabular}


Continuation of Chart 1

\begin{tabular}{|l|l|l|}
\hline Title & Proposal of Study & Synopsis \\
\hline $\begin{array}{l}\text { Clinical observations on } \\
\text { the value of reminiscences } \\
\text { in the aging process }{ }^{19} .\end{array}$ & $\begin{array}{l}\text { Case study with a } \\
89 \text {-year-old woman } \\
\text { on historical } \\
\text { reminiscences that } \\
\text { broke the barrier of } \\
\text { repression }\end{array}$ & $\begin{array}{l}\text { The children (50 years old or older) ask the elderly woman to } \\
\text { reveal past love stories that involved guilt caused by religious } \\
\text { values. She has a "blackout" and a spell of anger and crying. } \\
\text { In the past, her husband died and she was left with five small } \\
\text { children, experiencing moments of depression and suicide } \\
\text { attempts. The analysis took around two months with two } \\
\text { sessions per week, and conflicts over the forbidden themes } \\
\text { emerged, giving way to a reconciliation with herself, showing } \\
\text { that there is no time limit for the return of repressed memories. }\end{array}$ \\
\hline $\begin{array}{l}\text { Psychoanalytical } \\
\text { diagnostic }{ }^{20} .\end{array}$ & $\begin{array}{l}\text { Case study with } \\
\text { David Libermam } \\
\text { Algorithm (DLA) } \\
\text { psychoanalytic } \\
\text { diagnosis. }\end{array}$ & $\begin{array}{l}\text { fragments from an interview about a dream and a literary } \\
\text { work, with drive stagnation and various physical (respiratory) } \\
\text { symptoms. Phallic genital eroticism and intra-somatic libido } \\
\text { fixation is demonstrated in a poem. In the dream there is a } \\
\text { smaller and dramatic intra-somatic component. The interview } \\
\text { focuses on economic issues, the will to live and breathe the } \\
\text { air on a ranch. The DLA is cited as an instrument that orders } \\
\text { words, phrases, rhetoric, narratives, intonations and provides } \\
\text { the semiological ordering of discourse. }\end{array}$ \\
& \multicolumn{2}{|l}{}
\end{tabular}

Chart 2. Psychoanalytical approaches in old age. Uberaba, Minas Gerais, 2018.

\begin{tabular}{|c|c|c|}
\hline Títle & Study Proposal & Synopsis \\
\hline $\begin{array}{l}\text { The silencing of old } \\
\text { age: social erasure } \\
\text { and processes of } \\
\text { subjectivation }^{21} \text {. }\end{array}$ & $\begin{array}{l}\text { Reflection on } \\
\text { subjectivities of the } \\
\text { aged body and social } \\
\text { imaginary. }\end{array}$ & $\begin{array}{l}\text { Prejudice as everyday attitudes: social exclusion, subjective erasure, } \\
\text { disinterest in life history and fear of contact with old age due to link } \\
\text { to death. Terms like "the best age" mask the difficulty of accepting } \\
\text { this cycle. The passage of the "ideal of the self" regulates the subject } \\
\text { with marks of the insignias of the "other", in the hope of recognition. }\end{array}$ \\
\hline $\begin{array}{l}\text { The "third age", } \\
\text { subjectification and } \\
\text { biopolitics }^{22} \text {. }\end{array}$ & $\begin{array}{l}\text { Reflection of the } \\
\text { concept of the third } \\
\text { age as significant } \\
\text { in the reading } \\
\text { of biopower and } \\
\text { biopolitics. }\end{array}$ & $\begin{array}{l}\text { The significant "third age" brings new modalities of subjectivation } \\
\text { in the field of old age - such as the "end of life" for a "new time of } \\
\text { life". In the figure of biopower and biopolitics and the control of vital } \\
\text { processes, there is the medicalization of social space, the prevention } \\
\text { of diseases and the promotion of health. }\end{array}$ \\
\hline $\begin{array}{l}\text { Body and aging: } \\
\text { a psychoanalytic } \\
\text { perspective }^{23} \text {. }\end{array}$ & $\begin{array}{l}\text { Reflection on the } \\
\text { body, aging and } \\
\text { psychoanalysis. }\end{array}$ & $\begin{array}{l}\text { An unconscious body image is created, with identity, despite the } \\
\text { changes of the body over time. It is the phase of the "negative } \\
\text { mirror". There are losses in subjectivation, the reduction of the } \\
\text { libidinal flow, the search for ways out (diseases, therapeutics, use of } \\
\text { medication); ways of re-creating links and contacts with the "other". }\end{array}$ \\
\hline $\begin{array}{l}\text { The shadow of a } \\
\text { body that declares } \\
\text { itself: body, image } \\
\text { and aging } 24 \text {. }\end{array}$ & $\begin{array}{l}\text { Reflection on old } \\
\text { age and impacts on } \\
\text { the subject from the } \\
\text { psychoanalytic gaze. }\end{array}$ & $\begin{array}{l}\text { There is a mismatch between the timeless unconscious and the body, } \\
\text { within the scope of temporality. The reduction or loss of libido } \\
\text { causes the elderly to seek a certain narcissism, focusing on memories, } \\
\text { fantasies and pain. }\end{array}$ \\
\hline $\begin{array}{l}\text { Symptoms of the } \\
\text { elderly? } ?^{25} \text {. }\end{array}$ & $\begin{array}{l}\text { Reflection about } \\
\text { symptoms in the } \\
\text { elderly. }\end{array}$ & $\begin{array}{l}\text { The symptom in psychoanalysis contrasts with the biological and } \\
\text { cultural view of aging. The symptom may be old but not specific to } \\
\text { the elderly. Psychoanalysis does not deal with pathologies, but with } \\
\text { the subjectivated symptoms, in which the subjects are implicated. } \\
\text { There are no "symptoms of the old" and in the real and symbolic the } \\
\text { symptom can also be "enjoyed". }\end{array}$ \\
\hline
\end{tabular}


Continuation of Chart 2

\begin{tabular}{|l|l|l|}
\hline Títle & Study Proposal & Synopsis \\
\hline $\begin{array}{l}\text { "Old age? I think } \\
\text { the alternative ": } \\
\text { reflections on old } \\
\text { age and humor }{ }^{26} \text {. }\end{array}$ & $\begin{array}{l}\text { Reflection on humor } \\
\text { and old age, from } \\
\text { the starting point of } \\
\text { psychoanalysis. }\end{array}$ & $\begin{array}{l}\text { Old age is seen and lived through in a negative way and there is an } \\
\text { incessant search for happiness and a denial of suffering and death. } \\
\text { Examples of Freud's life are presented with the use of humor for the } \\
\text { relief of suffering and tolerance towards the ambiguities of life. }\end{array}$ \\
\hline $\begin{array}{l}\text { Old Age and Death: } \\
\text { Reflections on the }\end{array}$ & $\begin{array}{l}\text { Reflection on death } \\
\text { and aging in the light } \\
\text { of psychoanalysis. }\end{array}$ & $\begin{array}{l}\text { Death of friends and companions, loss of work, family and social } \\
\text { relations refer to real and symbolic losses. Death is not accepted } \\
\text { as natural, and religious ideas and beliefs are born out of the need } \\
\text { to make helplessness bearable. In suppressing the loved object, the } \\
\text { libido needs to be directed, a somewhat painful and slow process. }\end{array}$ \\
\hline $\begin{array}{l}\text { Vieillir en terre } \\
\text { étrangère: une } \\
\text { nouvelle épreuve de }\end{array}$ & $\begin{array}{l}\text { Reflection on aging } \\
\text { in the LTCF* and } \\
\text { migratory situation. }\end{array}$ & $\begin{array}{l}\text { Being old and outside the cultural context can generate suffering } \\
\text { of the social and psychic order. Foreign elderly people in the LTCF } \\
\text { experience psychic suffering because of the proximity of death and } \\
\text { because they do not see possibilities for the reformulation of life. } \\
\text { Listening spaces that see uniqueness as a conscious or unconscious } \\
\text { investment in culture are necessary, considering the symbolic resources. }\end{array}$ \\
\hline $\begin{array}{l}\text { Encounters and } \\
\text { solitudes of our } \\
\text { time }^{29} .\end{array}$ & $\begin{array}{l}\text { Reflection on the } \\
\text { relationship between } \\
\text { Psychoanalysis and } \\
\text { modern Philosophy, } \\
\text { highlighting: } \\
\text { adolescence, the } \\
\text { elderly and love. }\end{array}$ & $\begin{array}{l}\text { Adolescence, aging and love are described as moments of transition, } \\
\text { which are difficult to live through. With analytical work, it is possible } \\
\text { to assume "responsibility" for one's own destiny, which allows the } \\
\text { emancipation of the lived past, opening up the future through human } \\
\text { freedom, which is however limited. }\end{array}$ \\
\hline
\end{tabular}

* Long-Term Care Facility for the Elderly

Chart 3. Psychoanalytic Interventions in Long-Term Care Facilities for the Elderly. Uberaba, Minas Gerais, 2018.

\begin{tabular}{|l|l|l|}
\hline Title & Study Proposal & Synopsis \\
\hline $\begin{array}{l}\text { Too much love: } \\
\text { institutional care for } \\
\text { old age }{ }^{30} .\end{array}$ & $\begin{array}{l}\text { An ethnographic } \\
\text { case study, based } \\
\text { on a psychoanalytic } \\
\text { study of an LTCF* } \\
\text { on representations of } \\
\text { old age. }\end{array}$ & $\begin{array}{l}\text { Love, care and attention were understood by the professionals as } \\
\text { requirements for the proper exercise of the task, conceived as a gift } \\
\text { (talent) and independent of technical knowledge. The idea of this } \\
\text { talent as a disinterested action evidences care in a relationship of } \\
\text { "charity" and power. }\end{array}$ \\
\hline $\begin{array}{l}\text { L'apport de la } \\
\text { psychanalyse aux } \\
\text { soins en institution } \\
\text { gériatrique } 31\end{array}$ & $\begin{array}{l}\text { Reflection on } \\
\text { contributions of } \\
\text { psychoanalysis to } \\
\text { caregivers. }\end{array}$ & $\begin{array}{l}\text { There is transference and countertransference from the } \\
\text { professional in relation to the elderly; in addition, the same } \\
\text { experience frustrations in the constant losses of autonomy and } \\
\text { death. Psychoanalysis can contribute to the understanding of the } \\
\text { care practice for both the elderly and the caregiver. }\end{array}$ \\
\hline $\begin{array}{l}\text { The foreign relative: } \\
\text { the care of the other } \\
\text { in the geriatric } \\
\text { institution }{ }^{32} .\end{array}$ & $\begin{array}{l}\text { Quantitative- } \\
\text { qualitative } \\
\text { research, based } \\
\text { on psychoanalysis } \\
\text { and on cultural } \\
\text { representations. }\end{array}$ & $\begin{array}{l}\text { The foreign workers in the LTCF* were women, with a mean } \\
\text { age 39, from South America and Eastern Europe, had more } \\
\text { than 13 years of schooling, had resided in Italy for 10 years, were } \\
\text { mostly nurses or nursing technicians, 25\% had already suffered } \\
\text { discrimination. In interviews with 13 nursing directors, three } \\
\text { categories emerged: "safety for us" (aspects that unite and reassure), } \\
\text { "familiar but threatening" (fear of relatives and family members) and } \\
\text { "radically strange" (leaving one place and arriving in another). The } \\
\text { group activities showed that through the symbolic one can reduce } \\
\text { the sensation of strangeness to "ourselves", elaborating it, without } \\
\text { living in the denial of this "other". }\end{array}$ \\
\hline
\end{tabular}


Continuation of Chart 3

\begin{tabular}{|l|l|l|}
\hline Title & Study Proposal & Synopsis \\
\hline $\begin{array}{l}\text { Institutionalization of } \\
\text { old age and regression: } \\
\begin{array}{l}\text { a psychoanalytic view } \\
\text { of old people's } \\
\text { homes }\end{array}\end{array}$ & $\begin{array}{l}\text { Reflection of practical } \\
\text { reality in two LTCFs } \\
\text { in partnership with } \\
\text { universities, with } \\
\text { use of "Psychology } \\
\text { workshops", and } \\
\text { trips. }\end{array}$ & $\begin{array}{l}\text { The infantilization (speech, type of care) and psychological } \\
\text { regression of the elderly was observed through prostration, apathy } \\
\text { towards a routine; and also among caregivers, because only basic } \\
\text { needs were valued, the stimulus to self-care was non-existent. } \\
\text { There is a mortification of the 'Self' through the loss of subjectivity } \\
\text { and the notion of territory. The departure from the institution } \\
\text { (trips) sought re-signification, contact with the external world. }\end{array}$ \\
\hline $\begin{array}{l}\text { Old age as a } \\
\text { brand today: a } \\
\text { psychoanalytic view }{ }^{34} .\end{array}$ & $\begin{array}{l}\text { Report of experience } \\
\text { of working in a group } \\
\text { in a LTCF*. }\end{array}$ & $\begin{array}{l}\text { Activity carried out with four to six elderly women in four } \\
\text { meetings of a total of 16 residents. The narratives revealed the } \\
\text { silence of the institution regarding symptoms, an attempt to } \\
\text { protect desires, in contrast to the drivers of life and death. There } \\
\text { was a devaluation of the knowledge of the elderly; a feeling of } \\
\text { abandonment and helplessness; communication that was not } \\
\text { tolerated by the LTCF*; deletion of individual traits; and, repetition } \\
\text { of stories. }\end{array}$ \\
\hline $\begin{array}{l}\text { The unveiling of old } \\
\text { age: the contributions } \\
\text { of psychoanalysis } \\
\text { in the search for } \\
\text { meanings for the } \\
\text { experience of aging }\end{array}$ & $\begin{array}{l}\text { Experience report of } \\
\text { the relationship of } \\
\text { psychoanalysis, aging } \\
\text { and old age, with six } \\
\text { elderly persons. }\end{array}$ & $\begin{array}{l}\text { Experience has shown that there is an emotional, psychic life, and } \\
\text { the existence of unconscious processes that govern the behaviors, } \\
\text { actions and symptoms of very old people. }\end{array}$ \\
\hline
\end{tabular}

*Long Term Care Facilities For The Elderly

Chart 4. Representations of Old Age for Health Professionals in the Light of Psychoanalysis. Uberaba, Minas Gerais, 2018.

\begin{tabular}{|l|l|l|}
\hline Title & Study Proposal & Synopsis \\
\hline $\begin{array}{l}\text { Collective imaginary } \\
\text { of mental health } \\
\text { professionals regarding } \\
\text { aging } 3 \text {. }\end{array}$ & $\begin{array}{l}\text { Qualitative survey } \\
\text { on the collective } \\
\text { imaginary of mental } \\
\text { health workers. }\end{array}$ & $\begin{array}{l}\text { Two fields of affective-emotional meaning emerged: "suffering } \\
\text { and loneliness" and "age does not matter". This shows that } \\
\text { being old is seen as sad and lonely, but few professionals see the } \\
\text { possibility of creative and healthy lifestyles. }\end{array}$ \\
\hline $\begin{array}{l}\text { Death from the view } \\
\text { of a cleaning team }{ }^{37} .\end{array}$ & $\begin{array}{l}\text { Survey of views of } \\
\text { cleaning workers in a } \\
\text { geriatric nursing ward } \\
\text { on death. }\end{array}$ & $\begin{array}{l}\text { Four categories were observed: perception about death (repetition, } \\
\text { fear of fragility); death and religion (religious practice for managing } \\
\text { helplessness); death of the elderly (acceptance in this age cycle, } \\
\text { penalty); space offered to participants (reflection of finitude). }\end{array}$ \\
\hline
\end{tabular}

\section{Generationality and the psyche}

The article in this category is described in Chart

5 , and deals with generationality and the psyche.

Chart 5. Generationality and the psyche. Uberaba, Minas Gerais, 2018.

\begin{tabular}{|l|l|l|}
\hline Títle & Study Proposal & Synopsis \\
\hline $\begin{array}{l}\text { Transmission of } \\
\text { the psyche between } \\
\text { generations }{ }^{38} .\end{array}$ & $\begin{array}{l}\text { Reflection on a case in } \\
\text { the transmission of the } \\
\text { psyche. }\end{array}$ & $\begin{array}{l}\text { Elderly woman with a history of generational repetitions including } \\
\text { events such as: incest, denial and hiding facts, showing that } \\
\text { unprocessed psychic traumas can pass to future generations. }\end{array}$ \\
\hline
\end{tabular}




\section{DISCUSSION}

Elderly population growth in comparison with the general population ${ }^{6,9}$ and the distance from the Freudian gaze of "proscribing" psychoanalytic care to the elderly cannot be denied ${ }^{11,18}$.

Aging occurs from birth, but for psychoanalysis old age is the stage where the elderly are to be found $^{4}$. If the main subject of psychoanalysis is the unconscious, and if this does not age, in addition to the fact that "symptoms of the old" do not exist, the symptom itself brings the direction of analysis up to date ${ }^{6,10,19,37}$. One study showed that analysis with the elderly allowed the construction of knowledge of the real, through the elaboration of the process of guilt ${ }^{19}$. Thus, it is up to the analyst to create a relationship with their patient, so that the symptoms presented connect with healthy elements ${ }^{39}$.

The articles show that the classic approach needs to be reviewed when providing care in old age. There is a possibility of group actions, including the elderly individual, their family and the professionals who take care of them ${ }^{5,9,15,18}$.

Through varied contexts, old age is the cycle that occupies the most hospital beds. In this period the elderly receive clinical care while their unconscious remains active. Their symptoms bring up to date their psychic condition, their life history (and their neurosis) and their drives, all of which are there; it is, therefore, a unique analytical moment $t^{11,13,16}$.

Another niche is the home. An elderly person may be hospitalized (in conditions of intermediate or palliative care) in their home and, if there is no significant cognitive impairment, such an individual can be subject to psychoanalytic care ${ }^{12,19}$.

The non-aging of the unconscious and the maintenance of structure in the elderly, despite the physical and emotional condition that old age denotes, require other instruments of psychoanalytic intervention.

The intersubjectivity and importance of the subjective dimension, especially in the meaning of pain, recurrent falls, forgetfulness and dependence on care can adopt an empathetic route ${ }^{8,15}$. Or in the projective identification, passing from one affect to another, which may occur between the elderly and caregiver ${ }^{8,15}$.

The representations of old age in a social panorama bring a contrast of advances in various areas (sanitation, health, economy, politics, education) that extend life expectancy, access to goods and services, perspectives of well-being ${ }^{40,41}$. But these advances can create other issues of suffering, especially psychic.

The "ideal of the Self" regulates the subject with the insignia of the "Other", in the search for recognition and being loved, but not fulfilling this requirement can bring the haunting sense of failure; so that unprocessed changes reveal something we want no contact with, old age ${ }^{21}$.

Achieving old age (even from a biological point of view) for the present day (considering the past) is a success; and brings about a new symbolic and social experience.

Elderly men and women tend to become castrated with age, through difficulties in getting erections and menopause, which bring distress to the subjects; who may not want to give up what they were, and still less readjust to new life projects ${ }^{23}$. But to medicalize the social space, prevent health problems and promote health without subjectivation and the elaboration of life scenarios is unproductive.

Symptoms subjectivated in diseases, or as a form of pleasure, can make old age tragic and more acute, and the elderly may stop caring and become more and more detached from life. In this case, the analyst's function is to listen to human beings who speak, in an attempt to build a bridge between the real and the symptom ${ }^{38}$.

We are talking here of a subject with desires but a weakened body, which will require the revision of narcissistic ideals and the search of projects, to the limits of the body and to social and cultural questions, influencing daily life. It is the dilemma of the temporal body with a timeless unconscious ${ }^{24}$.

The loss of a loved one or an object that replaces it can generate grief with a high instinctual investment, and thus the libido needs to be redirected ${ }^{27}$. 
The fact of being in an LTCF reveals several contexts of institutional insertion: the decision of the family, an elderly person with multimorbidities and polypharmacy, dependent on a great deal of care.

The distress of the institutionalized elderly person is beyond the distress of the life cycle. There are losses in the body, but especially in the symbolic and imaginary dimensions, which generates introspective behavior and absence of openness to speech. One study showed that the notion of charity as a gift and the need of the elderly converge towards the intention of the "Other," which transitions from the power of the caregiver to the dependence of caring ${ }^{30}$.

However, LTCF professionals tend to suffer from psychic suffering, so they can receive psychoanalytic support for the constant experience of loss, lack of autonomy and proximity to death ${ }^{31}$ experienced by caring for elderly people.

Infantile and psychological regression, overvaluation of basic needs (analogous to childlike dependence), discouragement of self-care, lack of interaction between the elderly and the external world, and monotony through routines are described ${ }^{33}$.

The disinterest towards the elderly on the part of psychoanalysis as a whole, makes its contribution to the LTCF a distant reality; but there is much to be done in this space, whether through the elderly, family members or caregivers.

The view of the health professional about old age does not tend to be very different from the social perspective. Even if different visions were hoped for, they are usually negative. Research on social representations of old age and a good old age from the view of the elderly was due to being active or not and, of the people around them, by valorization or devaluation; and for both by economic, family and behavioral dimensions $s^{41,42}$.

The issue of sexuality and the support of social services (especially health) are not mentioned. Studies claim that it is not old age that determines the absence of desire or the diminution of sexual relations, but the complexity of desire that imposes new hues for sexuality in old age ${ }^{43,44}$.

\section{CONCLUSION}

Among the main gaps found in the literature are: the need for more clinical studies of psychoanalysis with the elderly, the mapping of experiences, knowledge of what psychoanalysts think in this clinical area, cognitive capacity in old age, psychoanalytic actions and psychoanalysis in Long Term Care Facilities for the Elderly.

Essential supports of psychoanalysis widely used in other life cycles (sexuality, free association, the symptom and its time and temporal chronological relationship, specific or more creative approaches) need to be adapted to the care of old age.

The scientific community and journals need to create pendular movements (of dialogue, of coming and going, of criticism) that stimulate not only the production and the interest of psychoanalysis, but also the training of psychoanalysts focused on actions in old age, a contemporary demand.

\section{REFERENCES}

1. Brasil. Instituto Brasileiro de Geografia e Estatística. Censo Demográfico 2010 [Internet]. Rio de Janeiro: IBGE; 2010 [acesso em 22 mar. 2018]. Disponível em: http://www.censo2010.ibge.gov.br/

2. Mucida A. Escrita de uma memória que não se apaga: envelhecimento e velhice. Belo Horizonte: Autêntica; 2014.
3. Torezan ZCF, Aguiar F. O Sujeito da psicanálise: particularidades na contemporaneidade. Rev Mal-estar Subj [Internet]. 2011 [acesso em 27 out. 2018];11(2):525-54. Disponível em: http://periodicos. unifor.br/rmes/article/view/4993/4000

4. Altman M. O envelhecimento à luz da psicanálise. J Psicanál. 2011;44(80):193-206. 
5. Lima PMR, Viana TC, Lima SC. Estética e poética da velhice em narrativas autobiográficas: um estudo a luz da psicanálise. Estud Pesqui Psicol. 2015;15(1):58-78.

6. Mucida A. Atendimento psicanalítico do idoso. São Paulo: Zagogoni; 2014.

7. Souza MT, Silva MD, Carvalho R. Revisão integrativa: o que é e como fazer. Einstein [Internet]. 2010 [acesso em 13 fev. 2018];8(1 Pt 1):102-6. Disponível em: http://www.scielo.br/pdf/eins/v8n1/ pt_1679-4508-eins-8-1-0102

8. Cherix K, Coelho Júnior NE. O cuidado de idosos como um campo intersubjetivo: reflexões éticas. Interface. 2017;21(62):579-88.

9. Genaro Junior F. Considerações sobre a clínica psicanalítica do envelhecimento no SUS: o CRINorte. Mais 60. 2016;27(66):20-45.

10. Mucida A. Direção do tratamento na clínica com idosos. Rev Bras Ciênc Envelhec Hum. 2015;12(3):245-55.

11. Silva JM, Moreira JO. Psicanálise e velhice: considerações clínicas. Ciênc Téc Vitiv. 2015;30(2):238-56.

12. Plotkin DA. Older adults and psychoanalytic treatment: it's about time. Psychodyn Psychiatr. 2014;42(1):23-50.

13. Fontoni MR, Oliveira WL, Kaneta CN. Winnicotti e o desafio do atendimento a pacientes idosos em estado confusional. Psicol Saúde Doenças. 2014;15(3):816-27.

14. Chessick RD. Special problems for the elderly psychoanalyst in the psychoanalytic process. J Am Psychoanal Assoc. 2013;61(1):67-93.

15. Castilho G. Psicanálise e velhice: o idoso é obsoleto? Trivium. 2012;4(2):48-58.

16. Pierron-Robinet G. Pour une approche intégrative de la maladie d'Alzheimer: pertinence et limites. Geriatr Psychol Neuropsychiatr Vieil. 2012;10(1):73-81.

17. Chase C. The aging of Anna Freud's diagnostic profile: a re-examination and re-application of the psychoanalytic assessment for older adults. Psychoanal Study Child. 2011;65:245-74.

18. Gil CA, Tardivo LSPC. A oficina de cartas, fotografias e lembranças como intervenção psicoterapêutica grupal com idosos. Mudanças. 2011;19(1-2):19-30.

19. Santos SS, Carlos AS. Observações clínicas sobre o valor das reminiscências no processo de envelhecimento. Barbarói. 2011;35:128-40.

20. Bodni O. Diagnóstico psicoanalítico. Subj Procesos Cogn. 2010;14(2):1-14.
21. Rosa MC. Vilhena J. O Silenciamento da velhice: apagamento social e processos de subjetivação. Rev Subj. 2016;16(2):9-19.

22. Birman J. Terceira idade, subjetivação e biopolítica. História Ciênc Saúde. 2015;22(4):1267-82.

23. Cherix K. Corpo e envelhecimento: uma perspectiva psicanalítica. Rev SBPH. 2015;18(1):39-51.

24. Vilhena J, Novaes JV, Rosa CM. A sombra de um corpo, imagem e envelhecimento. Rev Latinoam Psicopatol Fundam. 2014;17(2):251-64.

25. Mucida A, Pinto JM. Sintomas de velhos? Cad Psicanal (CPRJ). 2014;36(30):45-60.

26. Lima PMR, Viana TC, Lazzarini ER. "Velhice? Acho ótima, considerando a alternativa": reflexões sobre velhice e humor. Rev Mal-estar e Subj. 2011;11(4):1597-618.

27. Concentino JMB, Viana TC. A Velhice e a morte: reflexões sobre o processo de luto. Rev Bras Geriatr Gerontol. 2011;14(3):591-600.

28. Sittou R. Vieillir en terre étrangère: une nouvelle épreuve de l'exil. Psychol NeuroPsychiatr Vieil. 2008;6(1):23-31.

29. Corbella S. Encontros e solidões do nosso tempo. Rev Bras Psicanal. 2008;42(3):149-67.

30. Barbieri NA, Sarti C. Amor demais: o cuidado institucional à velhice. Vibrant 2015;13(1):71-88.

31. Charazac PM. L'apport de la psychanalyse aux soins en institution gériatrique. Geriatr Psychol Neuropsychiatr. 2014;12(2):193-8.

32. Carrano I, Grifo P. Estrangeiro, familiar: o cuidado do outro na instituição geriátrica. Rev Inter Mob Hum. 2012;20(38):163-79.

33. Rozendo AS, Justo JS. Institucionalização da velhice e regressão: um olhar psicanalítico sobre os asilos de velhos. Rev Kairós. 2012;15(8):25-51.

34. Silva BR, Finocchio AL. A velhice como marca da atualidade: uma visão psicanalítica. Vínculo. 2011;8(2):22-8.

35. Abrahão ES. O desvelar da velhice: as contribuições da psicanálise na busca de sentidos para a experiência do envelhecer. Rev SPAGESP. 2008;9(1):57-65.

36. Simões CHD, Ferreira-Teixeira MC, Aiello-Vaisberg TMJ. Imaginário coletivo de profissionais de saúde mental sobre envelhecimento. Bol Psicol. 2014;64(140):65-77.

37. Silva DPG, Kiyan L, Wanderley KS. O óbito sob a ótica da equipe de limpeza. Saúde Debate. 2009;33(81):140-7. 
38. Hartmann IB, Schestatsky S. Transmissão do psiquismo entre as gerações. Rev Bras Psicoter. 2011;13(2):992-1114.

39. Brasil KTR, Barcelos MAR, Arrais AR, Cárdenas CJ. A clínica do envelhecimento: desafios e reflexões para prática psicológica com idosos. Aletheia [Internet]. 2013 [acesso em 22 mar. 2018];(40):12033. Disponível em: http://pepsic.bvsalud.org/ scielo.php?script $=$ sci_arttext\&pid $=\mathrm{S} 1413$ 03942013000100011\&lng=pt\&tlng=pt

40. Silva MC, Ogata MN, Oliveira DC. O estado de arte das produções científicas nacionais das representações sociais do envelhecimento na perspectiva da saúde. Rev Kairós. 2015;18(Esp 19):49-63.

41. Brito A, Camargo B, Castro A. Representações sociais de velhice e boa velhice entre idosos e sua rede social. Rev Psicologia da IMED. 2017;9(1):5-21.
42. Fernandes JSG, Andrade MS. Representações sociais de idosos sobre velhice. Arq Bras Psicol [Internet]. 2016 [acesso em 10 maio 2018];68(2):4859. Disponível em: http://pepsic.bvsalud.org/ scielo.php?script $=$ sci_arttext\&pid $=\mathrm{S} 1809$ $52672016000200005 \& \operatorname{lng}=\mathrm{pt} \& \mathrm{t} \operatorname{lng}=\mathrm{pt}$

43. Vieira KFL, Coutinho MPL, Saraiva ERA. A sexualidade na velhice: representações sociais de idosos frequentadores de um grupo de convivência. Psicol Ciênc Prof [Internet]. 2016 [acesso em 13 fev. 2018];36(1):196-209. Disponível em: https://dx.doi.org/10.1590/1982-3703002392013

44. Alencar DL, Marques APO, Leal MCC, Vieira JCM. Fatores que interferem na sexualidade de idosos: uma revisão integrativa. Ciênc Saúde Colet. 2014;19(8):3533-42.

Received: August 18, 2018

Reviewed: October 23, 2018

Accepted: November 05, 2018 